\title{
Recenzja książki: Wojna hybrydowa Rosji przeciwko Ukrainie w latach 2014-2016, red. Walenty Baluk, Mykola Doroszko, Wydawnictwo Uniwersytetu Marii Curie-Skłodowskiej, Lublin 2017, ss. 280
}

$\mathrm{R}$ ok 2014 stał się momentem przełomowym w historii Ukrainy. Rewolucja Godności, aneksja Krymu, wybuch wojny na obszarze Donbasu przyczyniły się do bezpowrotnej zmiany nastawienia narodu ukraińskiego do życia politycznego wewnątrz państwa. Stały się podwaliną ku tworzeniu społeczeństwa obywatelskiego. $\mathrm{Na}$ gruncie polskich nauk o polityce powstał ogrom prac poruszających tematykę wydarzeń na Ukrainie ${ }^{1}$. Niewiele jednak $\mathrm{z}$ nich dokonuje wyczerpującej analizy rzeczywistych przyczyn, przebiegu czy prognozowanych skutków danego konfliktu. Na tym tle wyróżnia się monografia wydana w 2017 roku nakładem wydawnictwa Uniwersytetu Marie Curie-Skłodowskiej autorstwa Walentego Baluka oraz Mykoły Doroszko Wojna hybrydowa Rosji przeciwko Ukrainie w latach 2014-2016. Jak sam tytuł wskazuje, porusza ona problematykę konfliktu zbrojnego na Donbasie, przy czym warte podkreślenia jest to, że autorzy wyraźnie wskazali na rzeczywisty charakter wojny. Powiedziane jest o militarnej agresji Federacji Rosyjskiej przeciwko Ukrainie. Jest to szczególnie ważne, zwłaszcza w kontekście popularnego w polskich środowiskach badawczych określenia „wojna domowa” czy „operacja antyterrorystyczna przeciwko separatystom donieckim i ługańskim”2.

Recenzowana monografia składa się z sześciu rozdziałów, napisanych przez grono znanych badaczy zarówno polskich, jak i ukraińskich.

W rozdziale pierwszym Marek Pietraś (autor tej części) poruszył zagadnienie wojen hybrydowych w kontekście rozważań teoretycznych. Jak wskazał, celem tego roz-

M.in. B. Pacek, Wojna hybrydowa na Ukrainie, Wydawnictwo Rytm, Warszawa 2018; M. Klimecki, Z. Karpus, Czas samotności. Ukraina w latach 1914-2018, Wydawnictwo Bellona, Warszawa 2019.

2 M.in. P. Olbrycht, P. Chmura, Ukraińska operacja antyterrorystyczna jako odpowiedź na zagrożenie bezpieczeństwa we wschodniej Ukrainie, „Wschodnioznawstwo” 2018, issue 12, s. 74-84. 
działu jest „analiza tendencji zmiany i nowej jakości współczesnych konfliktów zbrojnych, określenie na tym tle istoty wojny hybrydowej oraz identyfikacja specyfiki wojny hybrydowej prowadzonej przez Rosję we wschodniej części Ukrainy”(s. 12). M. Pietraś postawił dwie istotne hipotezy badawcze:

1. W warunkach końca zimnej wojny i narastania procesów globalizacji pojęcie „wojna hybrydowa” staje się kolejną próbą nazwania procesu zmiany i nowej jakości współczesnych konfliktów zbrojnych.

2. Federacja Rosyjska zaangażowaniem w konflikt we wschodniej Ukrainie pojęciu „wojny hybrydowej” nadaje specyficzny sens, podporządkowując podejmowane działania realizacji priorytetów przyjętej strategii geopolitycznej³.

Jak słusznie zauważył autor, w postzimnowojennej rzeczywistości międzynarodowej dominują konflikty wewnątrzpaństwowe przy sporadycznym występowaniu konfliktów międzypaństwowych. Ochrona integralności terytorialnej państwa czy jego niezależności politycznej przestaje być dominującym czynnikiem wywołującym konflikt. Coraz częściej motywem staje się tożsamość określonej grupy etnicznej. Cechą wyróżniającą nowego rodzaju konfliktów jest zacieranie się wcześniejszych różnic pomiędzy wojną jako formą przemocy w stosunkach międzypaństwowych, zorganizowaną przestępczością i łamaniem praw człowieka na skalę masową ${ }^{4}$. Pomimo występowania wewnątrz poszczególnych państw, cechuje je wielość powiązań transnarodowych, np. w postaci aktywnego udziału najemników z państw ościennych. W tym miejscu jako przykład należy podać udział Czeczenów wspierających Ramzana Kadyrowa po stronie separatystów donieckich i ługańskich ${ }^{5}$.

Przez powszechność przekazu medialnego wojna hybrydowa stała się swego rodzaju spektaklem, rozgrywanym na oczach milionów widzów na całym świecie. Społeczeństwo obserwuje rozwój wydarzeń w czasie rzeczywistym, niejednokrotnie będąc świadkami ataków bombowych czy ostrzałów artyleryjskich.

Istotną cechą, na którą w swoich rozważaniach wskazał M. Pietraś, jest zaangażowanie struktur przestępczości zorganizowanej w takie konflikty. Należy zaznaczyć, że przedstawiciele tego typu ugrupowań nie mają na celu przejęcie władzy nad określonym terytorium. Liczy się przede wszystkim zysk finansowy (s. 19).

Wojnę hybrydową Rosji przeciwko Ukrainie na Donbasie wyróżnia przede wszystkim wsparcie funkcjonalne przy jednoczesnym unikaniu formalnego zaangażowania Rosji w konflikt. Tym samym władze rosyjskie unikają oficjalnej konfrontacji z Ukrainą. Jak słusznie zauważył autor, „,działaniom zbrojnym we wschodniej Ukrainie i aneksji Krymu towarzyszy fasada legalności podejmowanych działań, mimo krytyki ze strony społeczności międzynarodowej i prób dostarczania dowodów na łamanie prawa międzynarodowego" (s. 27). Jedną ze stron konfliktu pozostają rosyjskie nieoznako-

Ibidem, s. 12-13.

4 M. Kaldor, New and Old Wars. Organized Violence in a Global Era, Cambridge 1999, s. 1-2.

5 Корреспондент.net, Чеченці розповіли, скільки їх воює на Донбасі, https://ua.korrespondent. net/ukraine/3454071-chechentsi-rozpovily-skilky-yikh-vouiie-na-donbasi, inf. 20 VI 2020. 
wane jednostki wojskowe, czemu Rosja oficjalnie do dzisiaj zaprzecza, nawet pomimo przedstawiania wiarygodnych dowodów w postaci filmów czy zdjęć. Rosyjskie władze wykorzystują lokalne struktury paramilitarne we wschodniej Ukrainie prorosyjskich rebeliantów do walki przeciwko rządowi Ukrainy. Strukturom tym udzielają wsparcia wojskowego w postaci uzbrojenia, doradztwa, schronienia, finansowania i nawet dowodzenia. Niebagatelne znaczenie ma również zaangażowanie środków należących do tzw. miękkiej dyplomacji. Wykorzystanie środków masowego przekazu, takich jak np. stacja Russia Today nadająca praktycznie na całym świecie, przyczynia się do budowania określonego wizerunku zarówno Rosji, jak i Ukrainy na arenie międzynarodowej.

Warto również zwrócić uwagę na wykorzystywanie przez władze rosyjskie braku społeczeństwa obywatelskiego, nie tylko na Ukrainie, ale również na obszarze wszystkich państw poradzieckich. Brak społeczeństwa obywatelskiego stwarza sprzyjające warunki do stosowania elementów propagandy w różnej postaci. W efekcie doprowadza się do trwałych podziałów społecznych, braku współpracy pomiędzy poszczególnymi grupami czy wręcz wzajemnej wrogości. Następnie zyskuje się możliwość manipulowania napięciami społecznymi. Miało to miejsce również w przypadku Ukrainy zarówno podczas aneksji Krymu, jak i w momencie wybuchu działań zbrojnych na Donbasie.

W rozdziale drugim recenzowanej monografii została poruszono problematykę historycznych i politycznych uwarunkowań wojny rosyjsko-ukraińskiej. Autorami rozdziału są ukraińscy politolodzy - Mykola Doroszko oraz Wolodymyr Holowczenko. W swoich rozważaniach autorzy uwydatnili przede wszystkim historyczny kontekst wrogości rosyjskiej wobec Ukrainy. Podkreślają między innymi, że do pierwszych sporów pomiędzy narodami doszło już na początku XX wieku, kiedy to Ukraińcy dość aktywnie deklarowali dążenia do samostanowienia, co spotkało się z ostrym sprzeciwem Rosji (s. 33). Dokonywano aktywnych prób wprowadzenia reżimu bolszewickiego na obszarze ówczesnej Ukrainy. W pierwszej kolejności rozpętano wojnę ideologiczną, której celem było pokazanie społeczeństwu „burżuazyjnego” charakteru władzy ukraińskiej.

Warto podkreślić, że historyczny kontekst konfliktu rosyjsko-ukraińskiego na gruncie polskich nauk politologicznych dotychczas był nieczęsto poruszany. Dlatego też rozważania zawarte w recenzowanym rozdziale można uznać za swoiste novum, wprowadzające szerszą perspektywę badawczą dla badaczy zajmujących się problematyką relacji międzypaństwowych na obszarze postradzieckim.

Autorzy rozdziału przedstawili wyczerpujące wyjaśnienia kwestii krymskiej. Odwołali się do wydarzeń z najnowszej historii, przede wszystkim do momentu przekazania Półwyspu Krymskiego na rzecz Ukraińskiej SSR. Dokonali analizy czynników przesądzających o atrakcyjności Krymu zarówno dla Ukrainy, jak i dla Rosji (s. 44). Należy pamiętać, że Półwysep został przekazany Ukraińskiej SSR w sposób pokojowy w drodze uchwalenia Dekretu o przekazaniu obwodu krymskiego ze składu RFSRR do składu Ukraińskiej SSR ${ }^{6}$.

6 Закон СРСР «Про передачу Кримської області зі складу РРФСР у склад Украӥнської РСР» 1954, https://cyclop.com.ua/content/view/1082/58/1/5/\#6964, inf. 20 VI 2020. 
Z kwestią faktycznej przynależności państwowej Krymu w nierozerwalny sposób wiąże się problematyka funkcjonowania Floty Czarnomorskiej. W tym miejscu warto przedstawić kilka kluczowych informacji związanych z jej historią. Do formowania Floty Czarnomorskiej przystąpiono jeszcze w XVIII wieku, kiedy Krym został podbity przez Imperium Rosyjskie. Po zakończeniu wojny krymskiej (1853-1856) nastąpił upadek floty, zaś do jej odbudowy przystąpiono dopiero po 1870 roku. Tradycyjnie jej trzon stanowili Ukraińcy (w 1917 roku stanowili nawet 80\% ogółu marynarzy). Na skutek polityki prowadzonej przez władze radzieckie w tej kwestii nastąpiły znaczące zmiany. Represje polityczne lat 1935-1939 dotknęły również marynarzy ukraińskich. W garnizonach Floty Czarnomorskiej zakazano używania i nauczania języka ukraińskiego. Na stanowiska dowodzące mianowani byli wyłącznie Rosjanie, zaś oficerowie ukraińscy byli zmuszeni szukać zatrudnienia we flotach obcych państw. Do 1990 roku liczba Ukraińców na stanowiskach dowodzących nie mogła przekraczać 13\%7.

Po rozpadzie ZSRR Flota Czarnomorska w całości przeszła pod kontrolę Ukrainy na podstawie ustalonego podziału terytorialnego. Należy jednak wspomnieć o tym, że część jej składu oficerskiego ogłosiła bunt przeciwko władzy ukraińskiej. W tej sytuacji prezydenci Leonid Krawczuk i Borys Jelcyn zwołali pilne spotkanie, w trakcie którego postanowiono podzielić Flotę na dwie równe części. Z powodu przeciągających się negocjacji międzypaństwowych Flota w całości przeszła pod kontrolę rosyjską, przy czym oficerowie rosyjscy odmówili opuszczenia Sewastopola. W dniu 9 czerwca 1995 roku prezydenci L. Kuczma oraz B. Jelcyn dokonali ostatecznego podziału Floty: 18,5\% statków marynarki wojennej przeszło pod kontrolę Kijowa, zaś $81,7 \%$ - pod kontrolę Moskwy. Wojskowe bazy morskie w Izmaile, Odessie, Oczakowie, Kerczu, Donuzlawiu i Balaklawie, a także 10 baz awiacji morskiej znalazły się pod kontrolą Sił Zbrojnych Ukrainy ${ }^{8}$.

W okresie od 9 czerwca 1995 roku do 28 maja 1997 prezydenci Ukrainy i Rosji podpisali wiele porozumień, na mocy których Flota Czarnomorska Federacji Rosyjskiej mogła stacjonować na terytorium Ukrainy. Wyznaczono trzy miejsca jej stacjonowania - Sewastopol, Feodosję oraz Mikołajów. Ustanowiono limit żołnierzy na 25 tysięcy osób, 272 statki morskie oraz 22 statki powietrzne9 . Jak słusznie wskazali autorzy recenzowanego rozdziału, podpisując powyższe porozumienia Rosja skutecznie uniemożliwiła Ukrainie przystąpienie do Sojuszu Północnoatlantyckiego.

W omawianym rozdziale przedstawiono również projekty integracyjne utworzone i realizowane na obszarze postradzieckim. Poruszono kwestie funkcjonowania Eurazjatyckiej Wspólnoty Gospodarczej, Traktatu o Unii Celnej i Wspólnej Przestrzeni Gospodarczej, wreszcie Unii Celnej. Autorzy doszli do słusznych wniosków, podkreślając, że

7 Por. Soviet Armed Forces. Annual, Military-Naval Encyclopedia of Russia and the Soviet Union, ed. by D.R. Jones, Academic International Press, 1981.

8 Н. Дацька, Питання базування Чорноморського Флоту РФ на території Криму в контексті українсько-російських відносин, http://naub.org.ua/?p=1059, inf. 20 VI 2020.

9 С. Грабовський, I. Лосєв, Російський Чорноморський фбот: міфи та дійсність, https://ua.krymr. com/a/28168858.html, inf. 20 VI 2020. 
przez realizację powyższych inicjatyw integracyjnych Rosja pragnęła stworzyć na obszarze postradzieckim twór na wzór Unii Europejskiej, będący dla niej swoistą alternatywą.

Rozdział trzeci autorstwa Walentego Baluka oraz Nadii Gergało-Dąbek stanowi analizę wewnętrznych uwarunkowań wojny rosyjsko-ukraińskiej. Autorzy wysunęli interesującą koncepcję czterech poziomów transformacji systemowej na Ukrainie:

- politycznego (demokracji),

- ekonomicznego (rynku),

- państwowotwórczego (państwa),

- narodowotwórczego (narodu) (s. 71).

Należy zaznaczyć, że Rewolucja Godności z przełomu 2013/2014 roku ukazuje istotę przemian na poziomie trzecim i czwartym. To moment przełomowy dla procesu umacniania się ukraińskiego społeczeństwa obywatelskiego.

W swoich rozważaniach autorzy wyróżnili poszczególne etapy kształtowania się reżimu politycznego na Ukrainie. Są one następujące:

- 1991-1994 - rządy nomenklatury,

- 1994-2004 - kształtowanie systemu oligarchicznego,

- 2005-2014 - utrwalenie systemu oligarchicznego (s. 71).

Jak słusznie wskazali badacze, w pierwszym i drugim etapie doszło do zbyt powolnego procesu kształtowania się społeczeństwa obywatelskiego. $Z$ tego też powodu doszło do etapu trzeciego, czyli utrwalenia już istniejącego systemu oligarchicznego. Interes prywatny poszczególnych grup oligarchicznych górował nad interesem narodowym czy państwowym.

Walenty Baluk oraz Nadia Gergało-Dąbek w swoim rozdziale zamieścili również analizę uwarunkowań systemowych i politycznych w Federacji Rosyjskiej. Zaznaczyli, że w Rosji ukształtował się odmienny od ukraińskiego reżim hybrydowy nazywany modelem dominującej siły z mocno ograniczoną, ale wciąż realną przestrzenią polityczną (s. 77). Niewidoczna stała się granica pomiędzy partią rządzącą a państwem, zaś rola opozycji została mocno ograniczona.

Szczególną uwagę autorzy rozdziału zwrócili na uwarunkowania społeczne i kulturowe zarówno w Rosji, jak i na Ukrainie. Powszechnie wiadomo, że język rosyjski stanowi pewnego rodzaju kość niezgody dla narodu ukraińskiego. Od momentu rozpadu ZSRR i odzyskania niepodległości przez Ukrainę język ten nigdy nie został wyeliminowany ostatecznie z życia publicznego. Można nawet pokusić się o stwierdzenie, iż w społeczeństwie istniało ciche przyzwolenie na jego powszechne wykorzystywanie. Dotychczas nie stanowiło to najmniejszego problemu, jednakże sytuacja uległa diametralnej przemianie po 2014 roku. Wówczas okazało się, że obecność licznej ludności rosyjskojęzycznej czy powszechna ukraińsko-rosyjska dwukulturowość nie stanowią zagrożenia w swej istocie. Niebezpieczne zaś stało się wykorzystywanie mniejszości rosyjskojęzycznej przez Kreml jako tzw. „piątej kolumny” do ingerowania w wewnętrzne sprawy Ukrainy (s. 84). Osłabione przez system oligarchiczny państwo ukraińskie nie potrafiło skutecznie się obronić przed powstaniem i działalnością antysystemowych organizacji o charakterze prorosyjskim. 
Rozdział czwarty recenzowanej monografii został napisany przez Hryhoriya Perepelycię oraz Olenę Szewczenko - dwóch naukowców ukraińskich. Poruszono w nim problematykę militarnego i informacyjnego wymiaru wojny rosyjsko-ukraińskiej. Jak słusznie wskazali autorzy, istotną cechą politycznych i militarnych celów Rosji w wojnie z Ukrainą jest ich hybrydowy charakter, który przejawia się w manipulowaniu celami wojny na każdym z jej etapów (s. 111). W tym konflikcie nie określono ani celów wojny, ani terminów ich realizacji. Wiodącą rolę odgrywają środki militarne - przede wszystkim pod względem zaangażowania Federacji Rosyjskiej w konflikt. Natomiast dla strony ukraińskiej prym wiodą środki dyplomatyczno-polityczne, mające zapewnić ustabilizowanie zaostrzonej sytuacji na wschodzie państwa. Nacisk jest kładziony na jednostronne i wielostronne negocjacje, porozumienia, odwoływanie się do zasad prawa międzynarodowego itp.

Istotną cechą wojny rosyjsko-ukraińskiej, o której w swoich rozważaniach wspomnieli badacze, jest to, iż w przeważającej mierze nie występują w niej stricte regularne lub paramilitarne formacje wojskowe (s. 112). Należy podkreślić, że w początkowej fazie w konflikt były zaangażowane przede wszystkich bataliony ochotnicze, zarówno po jednej, jak i po drugiej stronie. Ukraińskie wojsko nie było w stanie podołać nowemu zadaniu ze względu na wieloletnią korupcję w szeregach, brak uzbrojenia, brak finansowania ze strony państwa i wiele innych powodów. Ze strony rosyjskiej zaś oficjalnie wojsko nie mogło być zaangażowane, gdyż wówczas oznaczałoby to bezpośrednie zaangażowanie Federacji Rosyjskiej, a więc konflikt międzynarodowy. Władze rosyjskie za wszelką cenę dążyły do ukazania wydarzeń na Donbasie jako wewnętrznego problemu Ukrainy, związanego z dyskryminacją narodu rosyjskojęzycznego.

Istotne informacje autorzy przedstawili w części rozdziału poświęconej wymiarowi informacyjnemu wojny rosyjsko-ukraińskiej. Potężny atak informacyjny ze strony rosyjskich środków masowego przekazu oraz ze strony służb specjalnych ujawnił silne i słabe strony systemu bezpieczeństwa informacyjnego Ukrainy oraz pokazał, iż $\mathrm{w}$ chwili obecnej bezpieczeństwo informacyjne pozostaje najbardziej wrażliwym komponentem bezpieczeństwa narodowego państwa (s. 132). Należy zaznaczyć, że agresja informacyjna Rosji przeciwko Ukrainie nie rozpoczęła się na przełomie 2013 i 2014 roku wraz z początkiem protestów na Majdanie. Jej początków można upatrywać już w 1991 roku, kiedy Ukraina odzyskała niepodległość i zaistniała jako niezależny aktor na arenie międzynarodowej. System rosyjskiej propagandy medialnej jest wyjątkowo rozwiniętym i skutecznym narzędziem wpływu nie tylko na społeczeństwo rosyjskie, ale również ludność rosyjskojęzyczną zamieszkującą w państwach tzw. bliskiej zagranicy. Jak wskazali autorzy rozdziału, najczęściej stosuje się następujące elementy wpływu:

- zniekształcanie faktów,

- publikowanie sfałszowanych zdjęć i nagrań wideo,

- wychwalanie politycznego kierownictwa Kremla i potęgi wojskowej Rosji,

- przypisywanie cech heroicznych rosyjskim wojskowym (s. 135).

Elementy wyżej wyszczególnione były niejednokrotnie wykorzystywane przeciwko innym państwom znajdującym się na obszarze postradzieckim. Podczas wojny sześcio- 
dniowej w Gruzji z 2008 roku zastosowano wszystkie powyższe działania celem dyskredytacji Gruzji na arenie międzynarodowej. Niejednokrotnie w rosyjskich serwisach informacyjnych publikowano zdjęcia zrobione podczas wojny w Czeczenii w latach 90. XX wieku, podając je za te przedstawiające sytuację w Gruzji ${ }^{10}$. Również wówczas podkreślano zasadność militarnej interwencji na terenie Osetii Południowej, tym samym wychwalając skuteczność politycznego kierownictwa Kremla i zarazem potęgi wojskowej Rosji ${ }^{11}$.

Rozdział piąty recenzowanej monografii dotyczy wymiaru międzynarodowego wojny rosyjsko-ukraińskiej. Autorzy (Jakub Olchowski, Walerij Kopijka, Wołodymyr Holowczenko oraz Eleonora Kirwiel) w swoich rozważaniach wysnuli tezę o tym, że Ukraina stała się podmiotem, a zarazem i przedmiotem rywalizacji Rosji z Zachodem na obszarze Europy Wschodniej (s. 154). Można stwierdzić, że konflikt na Donbasie stał się swoistym testem szeroko pojętego Zachodu przez Władimira Putina. Celem tego testu jest sprawdzenie, jak daleko Rosja może się posunąć w swoich działaniach względem tzw. bliskiej zagranicy bez narażania się na poważniejsze konsekwencje. Obserwując rozwój wydarzeń od 2014 roku, z całą pewnością można stwierdzić, że Unia Europejska ma niewielką możliwość wywierania realnego wpływu na Rosję. Jak słusznie wskazali autorzy rozdziału, poszczególne państwa europejskie (np. Niemcy czy Francja) pozwalają instytucjom unijnym działać dopóty, dopóki działania te nie stoją w sprzeczności z ich własnym interesem (s. 163).

Interesującym elementem omawianego rozdziału jest opis stanowiska Polski wobec wydarzeń na wschodzie Ukrainy. Ówczesne władze w sposób zdecydowany opowiedziały się po stronie Ukrainy, stwierdzając między innymi, że kwestia Krymu stanowi pierwszoplanowe znaczenie dla integralności terytorialnej Ukrainy w nowej rzeczywistości politycznej i społecznej (s. 204). Oficjalnie potępiono działania Rosji. Dostrzeżono wpływ konfliktu rosyjsko-ukraińskiego na kruchość poczucia bezpieczeństwa w Polsce.

Ostatni rozdział recenzowanej monografii autorstwa Oleksandra Zadorożnego, Oleksandra Sznyrkowa, Oleksija Czuhajewa oraz Walentego Baluka stanowi analizę konsekwencji agresji Federacji Rosyjskiej wobec Ukrainy. W swoich rozważaniach au-

10 W 2009 roku został opublikowany film dokumentalny autorstwa niezależnych dziennikarzy rosyjskich, demaskujący mechanizmy propagandy medialnej Rosji przeciwko Gruzji w trakcie wojny sześciodniowej w Osetii Południowej. Уроки русского, https://www.youtube.com/watch?v=0B8R8423em4, inf. 20 VI 2020.

$11 \mathrm{~W}$ momencie wybuchu wojny w Osetii Południowej rosyjskie serwisy informacyjne obiegło zdjęcie ówczesnego prezydenta Gruzji Micheila Saakaszwilego żującego własny krawat rzekomo w momencie wydania rozkazu rozpoczęcia ostrzału rzekomo pokojowych mieszkańców regionu. Tym zdjęciem zdyskredytowano prezydenta Gruzji jako osoby zdrowej psychicznie. Nie wspomniano równocześnie, że prowokacja ze strony rosyjskiej na terenie Osetii Południowej trwała już od jakiegoś czasu, łącznie ze zgrupowaniem wojsk rosyjskich przy granicach z Gruzją. Saakaszwili został przedstawiony w roli agresora, który siłą chce zmusić pokojowo nastawionych Osetyjczyków do powrotu pod jurysdykcję Tbilisi (formalnie Osetia Południowa od lat 90. XX wieku funkcjonowała jako parapaństwo). 
torzy odnieśli się do procesu aneksji Półwyspu Krymskiego przez Rosję i przedstawili następujące konkluzje:

1. Działania Federacji Rosyjskiej były brutalnym pogwałceniem wszystkich najważniejszych zasad ustanowionych przez prawo międzynarodowe. Najsilniejsze podmioty prawa międzynarodowego nie były w stanie efektywnie przeciwstawić się agresorowi.

2. Działania Federacji Rosyjskiej potwierdziły, że rosyjskie władze w stosunkach międzynarodowych preferują rozwiązania siłowe, zaś wszelkie zapewnienia o pokojowych zamiarach są jedynie fikcją.

3. Dokonując aneksji Krymu, Federacja Rosyjska w sposób rażący złamała postanowienia Memorandum Budapesztańskiego o gwarancji bezpieczeństwa i integralności terytorialnej Ukrainy wynikających z jej przystąpienia do Traktatu i nieproliferacji broni jądrowej z 1994 roku (s. 227-231).

Należy pamiętać, że wojna rosyjsko-ukraińska toczy się również w sferze gospodarczej. Po pierwsze, przybiera ona postać bezpośrednich działań o charakterze gospodarczym, mających negatywny wpływ na gospodarkę Ukrainy. Warto zaznaczyć, że były one stosowane już od 1991 roku, zaś ich nadrzędnym celem było wywarcie określonego wpływu na władze ukraińskie. Działania te przybierały postać np. ograniczeń importowych, ograniczeń energetycznych itp.

Po drugie, są to straty gospodarcze poniesione przez Ukrainę, spowodowane naruszeniem jej integralności terytorialnej oraz agresję wojskową (s. 232). Nie należy zapominać o tzw. wojnach gazowych, mających bezpośredni wpływ na stabilność energetyczną większości państw europejskich ${ }^{12}$.

Autorzy omawianego rozdziału dokonują próby formułowania perspektyw pokojowego rozwiązania konfliktu rosyjsko-ukraińskiego. Jak słusznie wskazali, ogólny charakter składanych deklaracji, a także brak zdecydowanej postawy Stanów Zjednoczonych Ameryki jako jednego z gwarantów suwerenności i integralności terytorialnej Ukrainy w ramach Memorandum Budapesztańskiego nie rokował dobrze dla formatu genewskiego jako mechanizmu pokojowego rozwiązania konfliktu rosyjsko-ukraińskiego (s. 243). Z perspektywy współczesności powyższa teza ma swoje potwierdzenie, gdyż konflikt na Donbasie wciąż nie został uregulowany, zaś postanowienia o zawieszeniu broni wciąż są łamane przez separatystów, wspieranych przez Rosję.

Podsumowując rozważania zawarte w recenzowanej monografii, należy stwierdzić, że jest to wyjątkowo cenne, obiektywne i profesjonalne źródło informacji na temat wojny rosyjsko-ukraińskiej. Wzbogaca w istotny sposób dorobek o charakterze politologicznym w dziedzinie badań nad Ukrainą. Autorzy monografii nie opierają swoich wywodów na źródłach, których wiarygodność mogłaby być w jakikolwiek sposób podważona. Świadczy to o wyjątkowym profesjonalizmie badawczym. Należy podkreślić, że rozważania zawarte $\mathrm{w}$ prezentowanych $\mathrm{w}$ monografii rozważaniach cechują się

12 Wojny gazowe miały miejsce w latach 90. XX wieku, w latach 2005-2006 (po rewolucji pomarańczowej na Ukrainie), w latach 2007-2008 oraz w 2009 roku. 
wyjątkową logicznością oraz trafnością oceny omawianych wydarzeń. Niebagatelne znaczenie dla walorów badawczych pracy posiada międzynarodowy zespół autorski. Ukraińscy badacze zaprezentowali odmienny sposób rozumienia bieżących wydarzeń z Donbasu oraz Krymu.

Warto również zwrócić uwagę na stronę edytorską omawianej monografii. Redaktorzy zadbali o przygotowanie biogramów autorów poszczególnych rozdziałów, co pozwala na przybliżenie sylwetek naukowych badaczy z Polski i Ukrainy. Poszczególne rozdziały jednakże nie są podpisane konkretnymi nazwiskami. Widnieją one jedynie w spisie treści, znajdującym się na początku monografii oraz we wspomnianym biogramie umieszczonym na ostatnich stronach.

\section{Bibliografia}

Dats'ka N., Pytannya bazuvannya Chornomors'koho Flotu RF na terytoriyi Krymu v konteksti ukrayins'ko-rosiys'kykh vidnosyn, http://naub.org.ua/?p=1059, inf. 20 VI 2020.

Hrabovs'kyy C., Losyev C., Rosiys'kyy Chornomors'kyy flot: mify ta diysnist', https://ua.krymr.com/a/28168858.html, inf. 20 VI 2020.

Kaldor M., New and Old Wars. Organized Violence in a Global Era, Cambridge 1999.

Klimecki M., Karpus Z., Czas samotności. Ukraina w latach 1914-2018, Wydawnictwo Bellona, Warszawa 2019.

Korrespondent.net, Chechentsi rozpovily, skil'ky yikh voyuye na Donbasi, https://ua.korrespondent.net/ ukraine/3454071-chechentsi-rozpovily-skilky-yikh-vouiie-na-donbasi, inf. 20 VI 2020.

Olbrycht P., Chmura P., Ukraińska operacja antyterrorystyczna jako odpowiedź na zagrożenie bezpieczeństwa we wschodniej Ukrainie, "Wschodnioznawstwo" 2018, issue 12, s. 74-84.

Pacek B., Wojna hybrydowa na Ukrainie, Wydawnictwo Rytm, Warszawa 2018.

Soviet Armed Forces. Annual, Military-Naval Encyclopedia of Russia and the Soviet Union, ed. by David. R. Jones, Academic International Press, 1981.

Uroki russkogo, https://www.youtube.com/watch?v=0B8R8423em4, inf. 20 VI 2020.

Wojna hybrydowa Rosji przeciwko Ukrainie w latach 2014-2016, red. W. Baluk, M. Doroszko, Wydawnictwo Uniwersytetu Marii Curie-Skłodowskiej, Lublin 2017.

Zakon SRSR «Pro peredachu Kryms'koyi oblastizi skladu RRFSR u sklad Ukrayins'koyi RSR» 1954, https:// cyclop.com.ua/content/view/1082/58/1/5/\#6964, inf. 20 VI 2020. 